Article

\title{
Proposed Methodology for the Calculation of Overview Distances at Level Crossings and the Inclusion Thereof in National Standards
}

\author{
Vladimír L'upták ${ }^{1, *}$, Maria Stopkova ${ }^{1}$ and Martin Jurkovič ${ }^{2}[$ \\ 1 Department of Transport and Logistics, Faculty of Technology, Institute of Technology and Business in \\ České Budějovice, 37001 České Budějovice, Czechia; stopkova@mail.vstecb.cz \\ 2 Department of Water Transport, Faculty of Operation and Economics of Transport and Communications, \\ University of Žilina, Univerzitná 8215/1, 01026 Žilina, Slovakia; martin.jurkovic@fpedas.uniza.sk \\ * Correspondence: luptak@mail.vstecb.cz
}

Received: 15 May 2020; Accepted: 11 July 2020; Published: 15 July 2020

\begin{abstract}
The aim of this article is to find a rational solution for increasing the safety of level crossings in the Czech Republic on the basis of a set of representative level crossings. The Czech Republic was deliberately chosen because of its geographical location, the number of level crossings on the network, and because, according to statistics from the Rail Safety Inspection Office, the country ranks as one of the highest for the number of accidents at level crossings. The rational solution being sought is one that achieves a balance between legislative, technical, and awareness-raising measures. In the practical part, great emphasis is placed on the assessment of the current state of Czech legislation. The identified discrepancies are resolved by adjusting calculations for overview distances and proposing changes to incorrect provisions. The main contribution of this paper is the comprehensive overview that it provides of level crossings and their safety. This overview includes a description of the current state of affairs, i.e., the number of level crossings, their location, classification, construction and type of equipment used, as well as an analysis of accidents and their frequency. The latter is in relation to the proposed construction and technical solution and subsequent assessment of the rationalisation possibilities and investments required to reconstruct or remove existing level crossings, thereby affecting the accident rate.
\end{abstract}

Keywords: railway crossing; accident rate; legislation; overview distances; level crossing safety equipment; warning signs; increase safety

\section{Introduction}

The Czech Republic covers an area of 78,863 $\mathrm{km}^{2}$ and has $9408 \mathrm{~km}$ of railway lines, which places it among those European countries with the highest density of railway networks. The road network, which stretches $1,300,000 \mathrm{~km}$, is similarly dense. When taking these two factors into consideration, it can logically be concluded that both networks combined to create a large number of level crossings. In total, there are 7870 of them (data provided by the Railway Administration of the Czech Republic in 2019-hereinafter referred to as SŽDC), which is equivalent to 0.8 level crossings for every $1 \mathrm{~km}$ of track. The safety, technical and transport solutions for this large number of level crossings form the main focus of this work. Within this context, it is clear that every level crossing poses the risk of a road user colliding with a railway vehicle. Unfortunately, accidents like these are not unusual and have been occurring since the dawn of rail transport. In response, railway operators have continuously tried to develop better and more sophisticated safety measures to prevent such accidents. These measures include simple warning signs (e.g., "Attention train"), mechanical barriers and state-of-the-art collision avoidance devices that utilise laser track detectors. 
However, the fact remains that despite the railway operators' best efforts, statistics show that the number of fatal accidents at railway crossings is only declining at a very slow pace. This is despite all sides acknowledging that the security devices used in the Czech Republic are among the most technologically advanced and of a very high level. All level crossings must comply with ordinances and standards, and all road users must comply with binding rules. The combination of these two factors should virtually eliminate the risks of a collision with a train.

Within this context, however, human error must also be taken into account. This covers a plethora of factors including lack of attention, overlooking safety warning signs and devices, as well as technical and natural influences, such as insufficient overview and poor visibility. This is evidenced by the fact that the majority of accidents occur at level crossings without barriers, which are equipped only with warning crosses or light signalling devices. Between 2015 and 2018, the Railway Safety Inspection Office recorded a total of 54 collisions at level crossings in the South Bohemia Region. Of these, 34 resulted in serious injury to those involved, and 13 in the loss of human life [1].

The aim of this article is to focus on the inconsistencies in Czech legislation and, in many respects, the benevolent approach to this. This approach enables different interpretations of individual provisions, even more so because of the inconsistency of existing standards and their nonbinding nature, which in turn is a reflection of the outdated wording of the regulations. This problem is further enhanced by the fact that other than the owner, no other authority is financially responsible for the maintenance of level crossings. As a result, rail management authorities, in their efforts to increase safety through the removal or closure of the most problematic and underused level crossings, often encounter resistance from the local municipal authorities, the majority of whom argue for the creation of a barrier. Unfortunately, this detracts from decreasing the number of level crossings, which would release more money for the upgrade and maintenance of the riskiest and busiest traffic intersections.

\section{Literature Review}

The basis for this article is an analysis of legal standards and regulations in the Czech Republic, namely the Act on Roads [2], the Act on Technical Requirements [3] and the Act on Road Traffic [4]. Similarly, standards and regulations on the design of crossroads [5], traffic management [6] and, particularly, on the technical standards for level crossing control and safety equipment (hereinafter referred to as CSE) [7] have also been taken into consideration. An important aspect within the design of the case study is the road and motorway design standards [8], in synergy with the road traffic regulations $[9,10]$. All these laws, decrees and standards were analysed for the purposes of this research.

In some publications [11,12], the intrusion of vehicles onto a level crossing is approached on the basis of detection and monitoring, whereas in others [13], it is approached in terms of warnings given by means of ultrasound and wireless communication, in particular where it concerns level crossings in rural areas, which is the case within our model examples. In Saunders et al. [14], the active elements in road and level crossings are analysed. Within this context, it is important to evaluate the braking distance, as discussed in [15]. In Widyastuti et al. [16], the authors look at a case study model of level crossings in Blitar. The capacity of the railway infrastructure is also important, as discussed in [17]. Capacity problems are mainly addressed by Gašparík [18] and Abramović [19,20], who point to new approaches for identifying this important aspect of rail transport. In Addabbo et al. [21], the safety of level crossings is studied in terms of targeted measurements and the analysis of the results. The detection and tracking of unauthorised intrusions are dealt with in [22]. Different situations at level crossings are analysed in [23]. An important element of this study is progressive and innovative level crossing technologies, as discussed in [24-26].

Simulating the impact of selected national values on the braking curves of vehicles equipped with ETCS is an integral part of, and one of the most important elements of, hazardous accidents at level crossings [27]. The use of aerodynamic brakes on high-speed trains is analysed in [28], which is closely related to train braking modes [29]. The calculation for braking distance is analysed and described 
in [30]. The deceleration rate for the calculation of safe braking distance [31] and the adhesion aspects involved in the calculation of safe braking distance [32] are preconditions for safety in emergency situations at level crossings.

Another basis for the analysis conducted in this article is the behaviour of truck drivers [33] and the methodology for researching the perceptions of drivers at level crossings [34]. A secondary problem is the design of an ecological interface for the reworking of level crossings [35]. In Read et al. [36], the authors addressed the issue of the warnings drivers are given when approaching passive level crossings and those they are given by alarm systems when approaching automatic level crossings [37]. In Zaman et al. [38], a case study for modelling railway accidents using maps is documented. All these sources were explored as a prerequisite for finding synergies with which to resolve the problems surrounding level crossings.

In Stopka et al. (2015) [39], the authors addressed the quality of public passenger transport services on the basis of the frequency and number of connections in public transport and the resulting higher accident rate at both the regional and European levels. This study was followed up by another [40] that sought to evaluate integrated public passenger transport on the basis of a case study and, secondarily, in terms of the safety of integrated transport systems as a whole. Skrúcany et al. (2019) [41] assessed the impact of the implementation of electric mobility in European countries, whereby the premise for the reduction of the sector's share in the production of greenhouse gases is the electrification of regional and secondary lines. Electrification has a significant impact on the number of accidents at level crossings, especially when vehicle height is exceeded, which is a particular problem during seasonal work in agricultural fields when the frequency of agricultural vehicles crossing level-crossings increases. These vehicles often collide with the overhead lines. It is also necessary to point out that collisions at level crossings that end in tragic consequences may also be the result of breaches of traffic safety and a lack of experience and practice among fresh drivers. These issues are looked at in depth by Akaateba et al. (2015) [42] and Salmon et al. (2013) [43]. In both, the authors demonstrated, on the basis of case studies, the psychological factors that influence professional drivers and recent graduates of a driving school course.

\section{Analysis of Current Methods for the Construction of Level Crossings}

A crucial contributory factor to the safety of level crossings is the means by which it is secured, the choice being determined by geographical location, which affects overview, and local conditions such as traffic intensity. The implication of this is that it is not necessary to install costly CSE in places where the intensity of traffic is minimal, or, to the contrary, to construct unsecured level crossings in high-risk places. However, at important junctions, there may be a mismatch between the norm and the regulations.

- Traffic intensity-Traffic intensity is an appropriate guide for determining the significance and choice of safety measures. The Czech technical standard 736380 (hereinafter referred to as ČSN 736380 standard [44]) states the formula for the transport moment calculation. The formula is based on the measurement of the number of vehicles that pass on a road per hour within ten hours. This number of vehicles is then multiplied by the average daily intensity of train services in both directions. The figure for the average intensity of train services is used because, in addition to the train services that run according to the timetabled schedule, rail traffic may also be affected by irregularities such as movements between operating control points. In the case of the complete upgrade of a level crossing, the ČSN 736380 [44] standard takes into consideration a traffic flow intensity some fifty times higher for the calculation. For the assessment of existing safety measures, the values of level intensities and capacities, dependent on the required level of traffic quality, are used.

- Length and width-Level crossing length is measured along the road axis. For level crossings without barriers, it is the distance of the intersections of this axis with the boundaries of the danger zone. For crossings with barriers, it is the distance of the intersections of this axis with the barrier bars. The crossing width is measured along the track axis and is equal to the distance 
of the intersections of this axis with the boundary of the free width of the road to the crossing. The width of the adjacent road should be at least $30 \mathrm{~m}$ from the edge of the rail track on either side. The minimum crossing width must be $5 \mathrm{~m}$, with exception to pedestrian- and cyclist-only crossings.

- Free height and free space-The free height measured between the crossing road and the overhead lines is given as the free height reduced by the set safe distance from the overhead line divided by traction. The passage space along the entire length and across the entire width of the level crossing must comply with the provisions set out in ČSN 73 6102. The free space is then defined along the whole length and free width and height.

- Spatial layout and connection to the road-According to the standards, a minimum distance of $10 \mathrm{~m}$ must be observed between the border of the junction and the danger zone of the level crossing. In the case of newly constructed level crossings, this is $30 \mathrm{~m}$. Not only does the distance to the nearest intersection play a major role in the resulting safety of the level crossing, but the angle of the intersection as well. For new level crossings, the required crossing angle is at least $75^{\circ}$. For existing crossings, it is recommended that this value be achieved during the design and implementation of the earliest upgrade. The level crossing must not ascend, arch or be in a transitional location. The longitudinal inclination of the track to the adjacent road must not exceed 3\%. The lateral slope is then given by the course of the track's vertical alignment.

- Construction-technical implementation of level crossings-Level crossings must, on the basis of their technical design, marking, overview and implemented security measures, ensure the safety of all road users, including persons with reduced mobility and orientation. The construction of roads at level crossings on national and/or regional lines must be demountable. The level crossing structure must be equipped with a protective wedge on both sides, the superstructure and the trackbed must be drained, and the shape of the rail used must be the same as in the adjacent section. The construction solution and/or modifications must correspond to the road traffic flows and loads, whilst ensuring the safety of the rail transport operation.

\subsection{Risk Analysis at Level Crossings Using the Ishikawa Method}

The cause-and-effect diagram is sometimes also called the Ishikawa diagram or even the herringbone diagram (see Figure 1). Its purpose is to determine the most likely cause of the problem we are trying to solve. This quality tool is usually used within a team, where all possible, and even unlikely, causes of the problem we are trying to solve are generated through brainstorming.

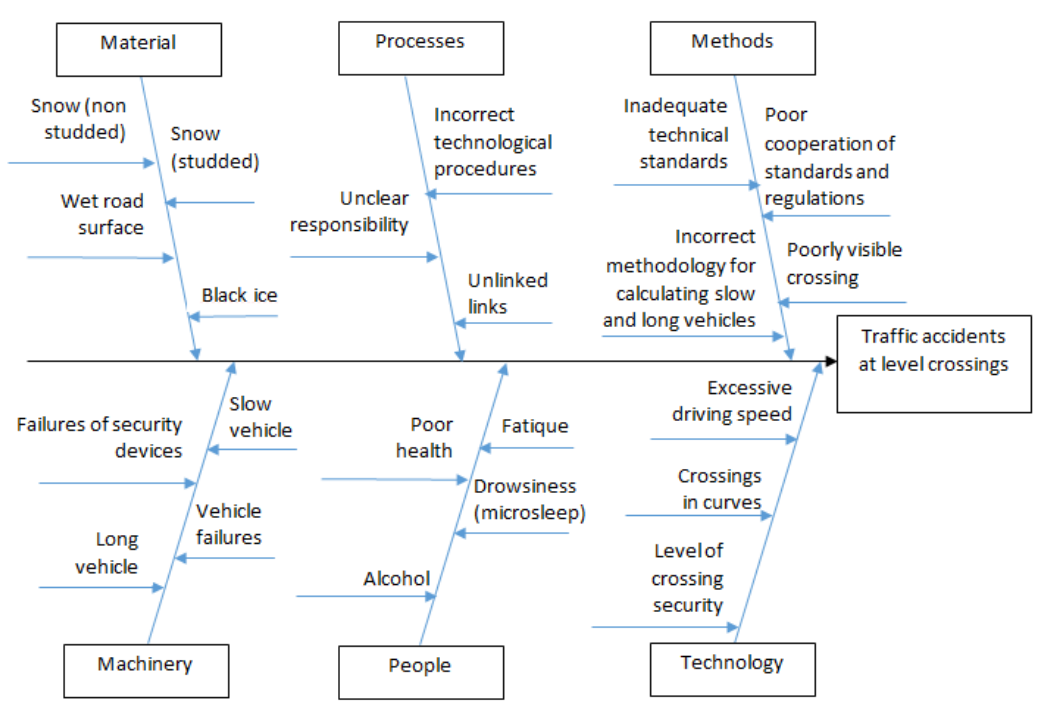

Figure 1. Risk analysis at level crossings using the Ishikawa method. 
After applying the methodology, the conclusion was drawn that in addition to the contribution that human factors make to the number of accidents at level crossings, the lack of coordination of regulations and technical standards also has a great influence. These regulations and standards will be subject to the optimisation of the calculation methods used in the construction of level crossings.

\subsection{Overview of Slowest and Longest Road Vehicles}

The most important factor for ensuring safety at level crossings is a standardised overview. The situation at level crossings equipped with a safety device is much easier than at level crossings with only a warning cross. Firstly, when calculating the distance required to stop a vehicle before a crossing, the determined speed takes into consideration the CSE used. The overview distance $D_{z}$ should be $40 \mathrm{~m}$ for a maximum authorised speed of $50 \mathrm{~km} / \mathrm{h}$, and $20 \mathrm{~m}$ for an authorised speed of $30 \mathrm{~km} / \mathrm{h}$. For functional category $\mathrm{C}$ roads, these distances are reduced by an additional $5 \mathrm{~m}$ (see Figure 2 and Table 1).

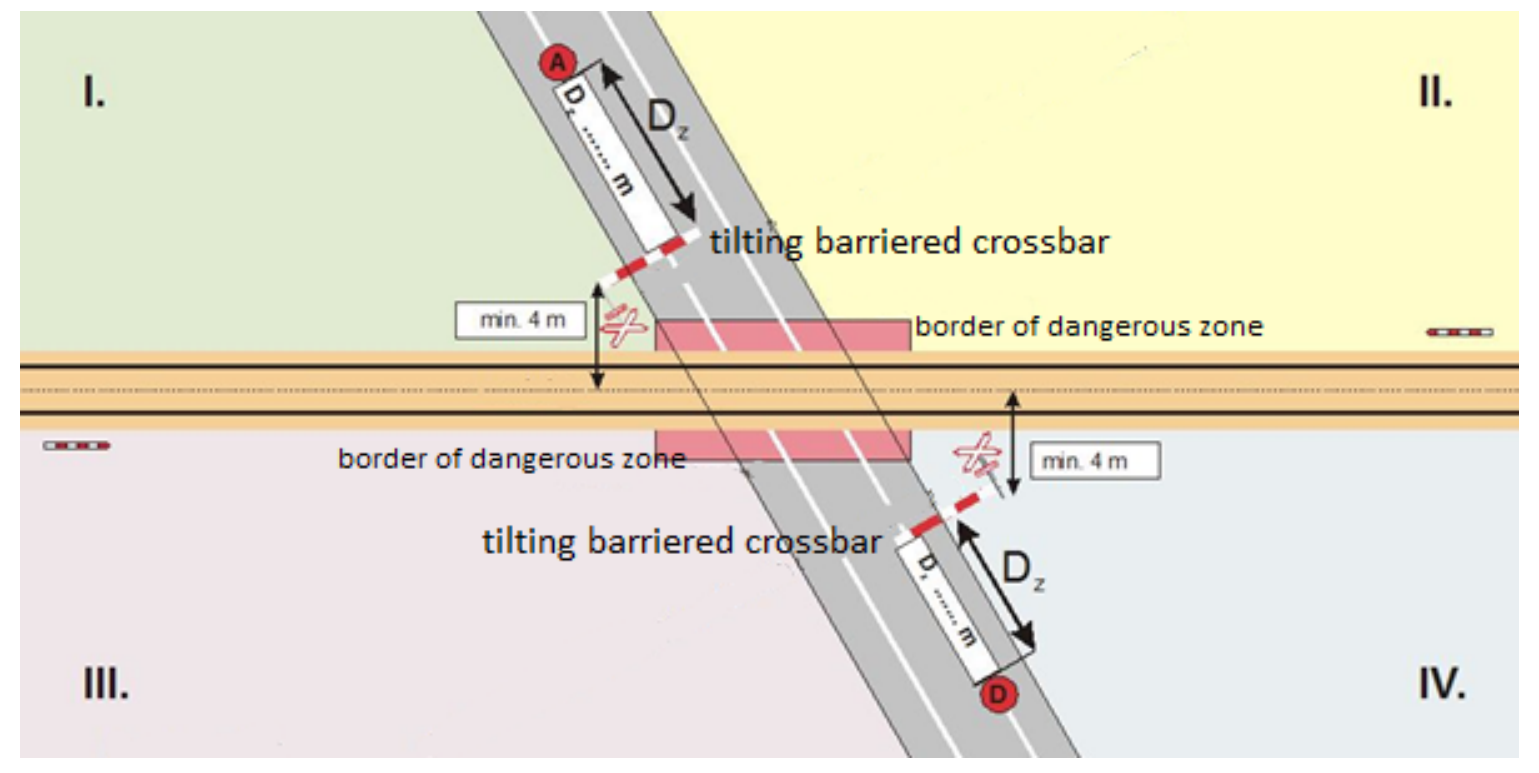

Figure 2. Overview distance required to stop before a level crossing with control and safety equipment (CSE). Source: [44].

Table 1. Overview distance $L_{r}$.

\begin{tabular}{cccccccc}
\hline Value & $\mathbf{k m} / \mathbf{h}$ & $\mathbf{1 0}$ & $\mathbf{2 0}$ & $\mathbf{3 0}$ & $\mathbf{4 0}$ & $\mathbf{5 0}$ & $\mathbf{6 0}$ \\
\hline Recommended for roads and local roads & {$[\mathrm{m}]$} & 16 & 32 & 48 & 64 & 81 & 97 \\
Shortest for main roads and local roads (categories A, B) & {$[\mathrm{m}]$} & 12 & 24 & 36 & 48 & 60 & 72 \\
Shortest for minor roads and lanes (category C and subcategory $\left.\mathrm{D}_{1}\right)$ & {$[\mathrm{m}]$} & 11 & 21 & 32 & 42 & 53 & 63
\end{tabular}

\section{Source: [44].}

For level crossings with only a warning cross, the situation is much more complicated. There are several variables that can influence each other. These include both the aforementioned overview distance $D_{z}$ for safe stopping and the unobstructed overview of the track (front of the railway vehicle) from a height of $1 \mathrm{~m}$ above the road, both in the field of vision of the road vehicle driver $\mathrm{L}_{\mathrm{r}}$ and that of the slowest road vehicle $L_{p}$.

The slowest road vehicle is the vehicle moving at $5 \mathrm{~km} / \mathrm{h}$. This speed is based on the historical value of the speed with which animals can be driven across a level crossing. Many safety experts have called for an increase or an adjustment of this value to take into account different local conditions. In the still valid CSD regulation [45], longitudinal vehicles are taken into account when calculating overview distances, whereby a length of $22 \mathrm{~m}$ is taken into consideration.(see Figure 3 and Table 2). 


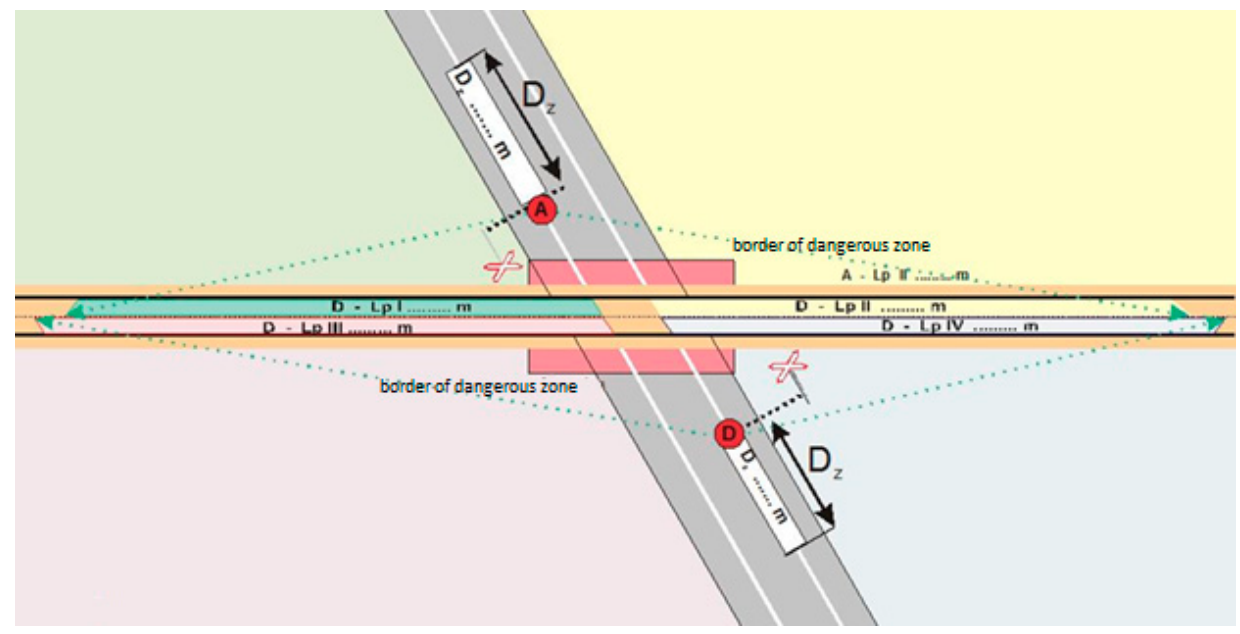

Figure 3. Driver's overview from the slowest road vehicle. Source: [39].

Table 2. The shortest distance $L_{p}$ on category $C$ and subcategory $D_{1}$ roads.

\begin{tabular}{ccccccc}
\hline \multirow{2}{*}{ Level Crossing Angle $\alpha\left[^{\circ}\right]$} & \multicolumn{7}{c}{ Line Speed $[\mathbf{k m} / \mathbf{h}]$} \\
\cline { 2 - 7 } & $\mathbf{1 0}$ & $\mathbf{2 0}$ & $\mathbf{3 0}$ & $\mathbf{4 0}$ & $\mathbf{5 0}$ & $\mathbf{6 0}$ \\
\hline 90 & 30 & 60 & 90 & 119 & 149 & 179 \\
80 & 30 & 60 & 90 & 120 & 150 & 180 \\
70 & 31 & 62 & 92 & 123 & 153 & 184 \\
60 & 32 & 64 & 96 & 127 & 159 & 191 \\
50 & 34 & 68 & 101 & 135 & 169 & 202 \\
45 & 36 & 71 & 106 & 141 & 176 & 211 \\
\hline \multicolumn{6}{c}{ Source: $[44]}$. \\
\end{tabular}

Currently, the greatest inconsistency between the ČSN 736380 [44] and SŽDC (ČSD) S 4/3 standards is the parameters regarding overview. The Czechoslovak Railways (ČSD) regulation [45] classifies overview according to observance as either very good, good, unfavourable, bad or insufficient. This closely corresponds to the choices made concerning the selected safety measures and the adjustments made for local conditions. For the purposes of the regulation, the same variables with a different designation are used. The braking distance $B$ is considered to be the standard overview distance $D_{z}$, whereby the value of the undisturbed overview $L_{r}$ is measured in the regulation as $1.2 \mathrm{~m}$ above the road surface and marked as $\mathrm{L}_{\mathrm{m}}$. The field of vision of the driver of the slowest vehicle is the same in both. However, what is different and essential is the possibility of halving the overview distances $L_{m}$ and $L_{p}$ in the case of an unfavourable overview. In the case of poor visibility, the regulation goes even further and cuts the braking distance B in half, including the above, and in contrast to the ČSN 736380 [44] standard, does not take into consideration the use of the P6 warning sign "Stop, give way!".

\section{Proposed Methodology for Calculation of Overview for the Slowest Vehicle}

In light of the statistics from the Rail Safety Inspection Office on the number of accidents at level crossings, including their consequences in terms of fatalities, injuries and property damage, it is essential to devise effective procedures to mitigate the risks of such accidents occurring. Professional articles and studies published abroad serve as a valuable source of information on this. Given the direct connection with the situation in the Czech Republic, these provide guidance for a possible alternative approach. Similarly, a comparative analysis of these guidelines that deal with a similar topic and the conclusions drawn is equally interesting. Combined, these guidelines provide an unbiased point of view that can be used to verify the correctness of any judgment concerning the proposed methodology. Assessing the feasibility of the application of the proposed measures in practice is an important part of this proposal. 
In terms of rationalisation, the data on rail network density and the number of level crossings reveal a difficult situation with regard to finding a uniform technical solution. However, for the selected sample of level crossings, it was possible to propose some partial, economically acceptable measures to improve safety measures that can feasibly be implemented on a general scale. This was the top priority. Future areas of interest and possible applications of current state-of-the-art technologies, including detection systems, ETCS technologies and new active safety features implemented directly in vehicles are also highlighted.

The analysis and design are focused on the region of South Bohemia, which is a suitable candidate because of the high density of level crossings and their geographical locations, thereby providing relevant results that may be extrapolated to generate national statistics. Outputs from the level crossing passport serve as a source of basic registration data.

\subsection{Problematic Overview}

The dual assessment of the overview is the first important area to consider. A good overview of the track is a key factor for ensuring safe operation. It is often the case that the assessed overview is only seasonal. Some crops planted in fields near a level crossing can grow to heights of over two metres, thereby (completely) blocking the overview of the track. In reality, there is little that can be done about this other than buying the land. It is important to note that it is impossible for the state to invest resources for this purpose. This also applies to possible interventions concerning crops or the cutting of trees.

If administrators want to properly secure and operate level crossings in order for the level crossings to be subject to similar circumstances, then according to the applicable standard, there is no other option than to install the P6 warning sign "Stop, give way!". This ensures that the standardised values $\mathrm{L}_{\mathrm{r}}$ and $\mathrm{L}_{\mathrm{p}}$ focus only on the slowest vehicle and that the value for the field of vision of the driver of the road vehicle is no longer taken into consideration.

\subsection{Proposal to Adjust the Speed of the Slowest Vehicle}

In 2012, an update of ČSN 736380 (marked as Z2) was issued, which came into effect in 2013. It was an attempt to unify the wording of the standard according to related laws and decrees. It sought to repeal the ČSD S 4/3 regulation and uniformly subordinate the construction and technical execution of all regulations to the current standard. The fundamental problem with this lies in the assessment of the behaviour of the slowest vehicle on a level crossing and the algorithm for calculating this. According to Z2, if the driver passes the danger zone on the remote side, it is assumed they will start to accelerate uniformly. This substantially changes the situation and fully reflects the current assessment of the overview at level crossings according to the ČSN 736102 (2017) standard. However, when the proposal was put forward to increase the speed of the slowest vehicle up to $10-15 \mathrm{~km} / \mathrm{h}$, as is the case in neighbouring states, it was met with immediate resistance. According to the current conclusions, the increase could be in the range of $5-10 \mathrm{~km} / \mathrm{h}$, taking into account the current local conditions. The overview distance $\mathrm{L}_{\mathrm{p}}$ is therefore unnecessarily demanding when consideration is given to the "historical" speed of $5 \mathrm{~km} / \mathrm{h}$ and the support given to resisting the repeal of the ČSD S 4/3 regulation. (see Table 3).

Table 3. Vehicle group and overview determination.

\begin{tabular}{cccc}
\hline Group & Vehicle & Vehicle Length $[\mathrm{m}]$ & Uniform Acceleration $\left[\mathrm{m} / \mathbf{s}^{\mathbf{2}}\right]$ \\
\hline 1 & Car and van & 6 & 2.2 \\
2 & Garbage truck, truck, bus & 10 & 1.7 \\
3 & Articulated bus, tractor and trailer or semitrailer & 18 & 1.3 \\
4 & Longest vehicle according to Act No. 361/2000 Coll. & 22 & 1.2 \\
\hline
\end{tabular}

Source: [39]. 
In light of the current technical parameters of vehicles and the state of the infrastructure, it is necessary to increase the speed to the maximum possible, thereby taking into account the local and technical conditions. It is this change in the ČSN $736380 \mathrm{Z} 2$ standard that provides the solution to the disputed situation with regard to the placement of the P6 warning sign "Stop, give way!". The calculation for the speed of the slowest vehicle and its uniform acceleration from the $4 \mathrm{~m}$ border from the axis of the track edge until it leaves the danger zone is taken into consideration. Thus, $\mathrm{v}_{\mathrm{sn}}=0 \mathrm{~km} / \mathrm{h}$ is considered the initial speed, and the time $\mathrm{t}_{\mathrm{p}}=0 \mathrm{~s}$. The current method is correct because the traffic restrictions used are, in many cases, inevitable and even required by the police of the Czech Republic. The current wording of the standard or regulation does not address this, and the calculated values are therefore based on a constant vehicle speed while passing through the danger zone, without stopping before the level crossing. The provisions of amendment $Z 1$ are therefore currently in force, with $Z 2$ revoked and replaced by amendment $Z 3$ at the request of the Railway Safety Inspection Office, with work on a proposed amendment Z4 underway (see Table 4).

Table 4. Driver's observation and reaction time.

\begin{tabular}{ccccc}
\hline & \multicolumn{4}{c}{$\mathbf{t}_{\mathbf{1}}[\mathbf{s}]$} \\
\cline { 2 - 5 } Road Category & \multicolumn{4}{c}{ Overview Conditions } \\
\cline { 2 - 5 } & $\begin{array}{c}\text { Recommended } \\
\text { Value }\end{array}$ & $\begin{array}{c}\text { Smallest } \\
\text { Value }\end{array}$ & $\begin{array}{c}\text { Recommended } \\
\text { Value }\end{array}$ & $\begin{array}{c}\text { Smallest } \\
\text { Value }\end{array}$ \\
\hline $\begin{array}{c}\text { Main roads and local roads } \\
\text { (categories A, B) }\end{array}$ & 2.0 & 1.5 & 3.5 & 2.0 \\
\hline $\begin{array}{c}\text { Minor roads and lanes } \\
\text { (category C, subcategory D1) }\end{array}$ & 1.5 & 1.0 & 3.5 & 1.0 \\
\hline $\begin{array}{c}\text { Purpose-built roads } \\
\text { (field and forest roads) }\end{array}$ & 1.5 & 1.0 & 3.5 & 1.0 \\
\hline & \multicolumn{2}{c}{ Source: $[44]}$.
\end{tabular}

The unsolved and dangerous situation arising from the use of the P6 warning sign "Stop, give way!" is also highlighted by Kubo [45], who analysed critical points in the region of South Bohemia. In particular, he put the spotlight on one level crossing from 1950, which only features warning crosses and the P6 warning sign, with a line speed of $100 \mathrm{~km} / \mathrm{h}$, which is permissible under Decree 177/1995 Coll. on the basis of $\S 88$. [46].

The calculation proves that when applying the formula for the slowest vehicle with a length of $22 \mathrm{~m}$, travelling at a constant speed of $5 \mathrm{~km} / \mathrm{h}$ before and beyond the danger zone without stopping, the overview distance complies with the ČSN 736380 Z1 standard. If the driver respects the markings and brings the vehicle to a complete standstill, and then subsequently starts moving forward again, the required overview distance increases by $18 \mathrm{~m}$, which is unsatisfactory. Nobody responsible (except the authors of the standard) is likely to address this. Placing the "Stop, give way!" sign, therefore, eliminates the need to maintain the $L_{r}$ decision field. In this case, however, the $L_{p}$, according to the ČSN $736380 \mathrm{Z1}$ standard, which is based on the formula and table values related to the vehicle moving at a constant speed of $5 \mathrm{~km} / \mathrm{h}$ for the whole time, is subsequently incorrectly evaluated. For the sake of clarity, it is, therefore, necessary to calculate the minimum value of $L_{p}$ for the selected crossing pattern according to the valid standard, whilst maintaining a constant speed. This value is then compared with the calculation for the vehicle that comes to a stop at the markings and then accelerates back up to the intended speed of $5 \mathrm{~km} / \mathrm{h}$. When drawing up the formula for a uniformly accelerating vehicle, it is necessary to consider the acceleration of the guide, depending on the respective group of vehicle, as indicated in the ČSN 736102 standard, the observation and reaction time of the driver according to the category of road, and the way in which the level crossing is secured in terms of the ČSN 737380 (2004) standard. [47]. 
The calculations in this article deal with actual values, which are taken into account by the ČSN 736380 standard, as is the assessment of their correctness. According to the tables specified in the ČSN 736380 standard, the passport kept by the administrator evaluates overview distances regardless of traffic restrictions. The calculations of the overview distance for the slowest road vehicle are currently flat-rate and based on the following formula (1):

$$
L_{p}=\frac{V_{z}}{V_{s n}} \times\left(D_{p}+D_{s}\right)
$$

where

$V_{z}$ line speed on the adjacent section and through the level crossing $[\mathrm{km} / \mathrm{h}]$

$D_{p} \quad$ level crossing length measured along the road axis [m]

$D_{s}$ length of the longest road vehicle (maximum permissible length of a truck is $22 \mathrm{~m}$ ) [m]

$V_{s n}$ speed of the slowest road vehicle $[\mathrm{km} / \mathrm{h}]$

$$
L_{p}=\frac{30}{5} \times(7.8+12)=118.8 \mathrm{~m} .
$$

The overview conditions are satisfactory because the minimum standard required $L_{p}$ of $118.8 \mathrm{~m}$ is less than the actual measured value of $128 \mathrm{~m}$. (see Figure 4 and Table 5).

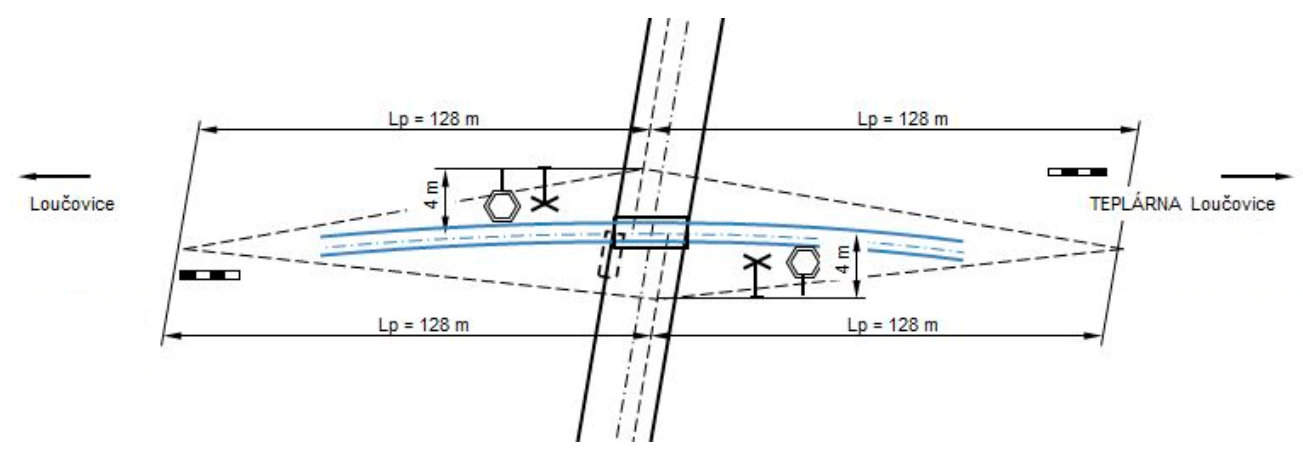

Figure 4. Situational drawing of level crossing P6133 with marked polygons. Source: authors.

Table 5. Measured input data $\mathrm{L}_{\mathrm{p}}$ for level crossing P6133.

\begin{tabular}{lc}
\hline Length of the level crossing & $7.8 \mathrm{~m}$ \\
Length of the longest vehicle & $12.0 \mathrm{~m}$ \\
Line speed through the level crossing & $30 \mathrm{~km} / \mathrm{h}$ \\
Speed of the slowest vehicle & $5 \mathrm{~km} / \mathrm{h}$ \\
Overview distance for the slowest $\mathrm{L}_{\mathrm{p}}$ vehicle & $128 \mathrm{~m}$ \\
Uniform acceleration extrapolated for $\mathrm{D}_{\mathrm{s}} 12 \mathrm{~m}$ & $1.5 \mathrm{~m} / \mathrm{s}^{2}$ \\
Observation and response time according to Article 7.4, Category III road, minimal & $2 \mathrm{~s}$ \\
\hline
\end{tabular}

Source: authors.

In addition to a warning cross, the level crossing is also fitted with the P6 warning sign "Stop, give way!". If the driver stops their vehicle based on this command, the calculation parameters will also change. Two more variables are added to the formula to reflect this. The basic formula is based on the cancelled amendment to the ČSN $736380 \mathrm{Z} 2$ standard but does not take into consideration the vehicle accelerating uniformly at the maximum speed limit through the level crossing. Instead, it assumes that the vehicle accelerates from 0 to $5 \mathrm{~km} / \mathrm{h}$ and continues at this constant speed while passing through the danger zone. The proposed formula (2) is, therefore, as follows:

$$
L_{p}=\frac{V_{z}}{3.6} \times\left(t_{1}+t_{a}+t_{k}\right)
$$




$$
\begin{gathered}
t_{a}=\frac{V_{p} / 3.6}{V_{z}}=\frac{5 / 3.6}{1.5}=0.93 \mathrm{~s} \\
D_{0}=\frac{V_{z} \times t_{a}^{2}}{2}=\frac{1.5 \times 0.93^{2}}{2}=0.65 \mathrm{~m} \\
D_{x}=\left(D_{p}+D_{s}\right)-D_{0}=(7.8+12)-0.65=19.15 \mathrm{~m} \\
t_{k}=\frac{D_{x}}{V_{p} / 3.6}=\frac{19.15}{5 / 3.6}=13.79 \mathrm{~s}
\end{gathered}
$$

where

$V_{y} \quad$ line speed on the adjacent section and through the level crossing $[\mathrm{km} / \mathrm{h}]$

$D_{p} \quad$ level crossing length measured along the road axis [m]

$D_{s}$ length of the longest road vehicle (maximum permissible length of a truck is $22 \mathrm{~m}$ ) [m]

$V_{p}$ speed of the slowest road vehicle $(5 \mathrm{~km} / \mathrm{h}$ is considered) $[\mathrm{km} / \mathrm{h}]$

$V_{z} \quad$ uniform acceleration according to group $\left[\mathrm{m} / \mathrm{s}^{2}\right]$

$D_{0} \quad$ distance travelled from 0 to the speed of the slowest vehicle [m]

$D_{x} \quad$ distance travelled at a constant speed of the slowest vehicle [m]

$t_{a} \quad$ time taken to accelerate from 0 to the slowest vehicle speed [s]

$t_{k} \quad$ time required to drive distance $\mathrm{D}_{\mathrm{x}}[\mathrm{s}]$

$t_{1}$ driver observation and response time [s]

$$
L_{p}=\frac{V_{z}}{3.6} \times\left(t_{1}+t_{a}+t_{k}\right)=\frac{30}{3.6} \times(1+0.93+13.79)=131 \mathrm{~m}
$$

When using the P6 warning sign "Stop, give way!", the overview distances for the selected level crossing P6133 are unsatisfactory. This is because the minimum calculated length $L_{p}$ of $131 \mathrm{~m}$ (for a vehicle starting after stopping) is greater than the actual measured length of $128 \mathrm{~m}$. If all variables are taken into consideration, in the case of acceleration from $0 \mathrm{~km} / \mathrm{h}$, the moment the front of the approaching railway vehicle is observed, the driver of the slowest vehicle, with a distance of $12 \mathrm{~m}$ to cover, would not manage to cross the level crossing in time, and, therefore, a collision would occur.

For comparative purposes, calculations were also made for another level crossing, specifically P6139, located near the village of Ujezdec. It is the most common type of single track level crossing with a minimum length of $6.5 \mathrm{~m}$, almost ideal angle of $105^{\circ}$, lying on a category B road with a P6 warning sign "Stop, give way!" on both sides. (see Figure 5 and Table 6).

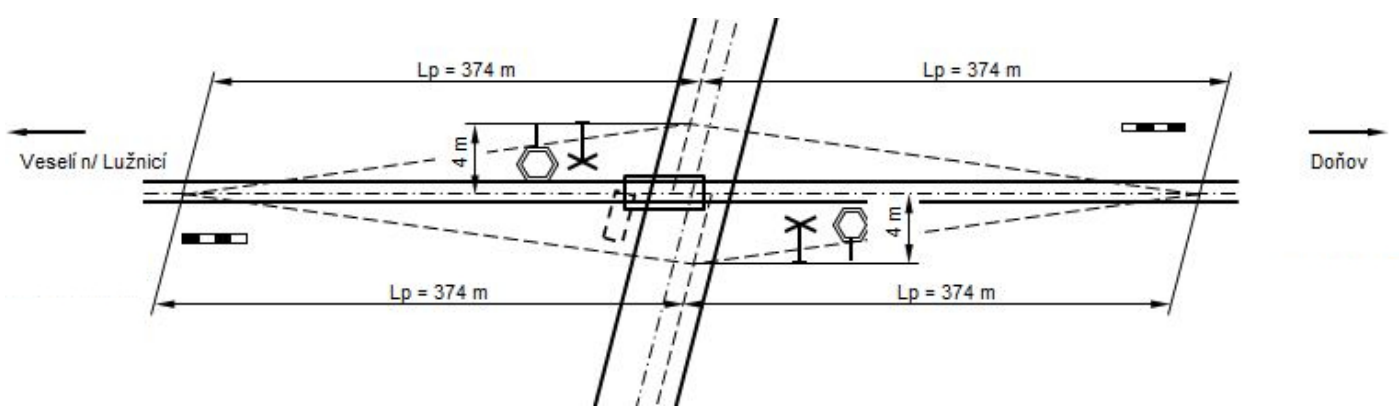

Figure 5. Situational drawing of level crossing P6139 with marked polygons. Source: authors. 
Table 6. Measured input data $\mathrm{L}_{\mathrm{p}}$ for level crossing P6139.

\begin{tabular}{lc}
\hline Length of the level crossing & $6.5 \mathrm{~m}$ \\
Length of the longest vehicle & $22.0 \mathrm{~m}$ \\
Line speed through the level crossing & $65 \mathrm{~km} / \mathrm{h}$ \\
Speed of the slowest vehicle & $5 \mathrm{~km} / \mathrm{h}$ \\
Overview distance for the slowest $\mathrm{L}_{\mathrm{p}}$ vehicle & $374 \mathrm{~m}$ \\
Uniform acceleration extrapolated for $D_{\mathrm{s}} 22 \mathrm{~m}$ & $1.2 \mathrm{~m} / \mathrm{s}^{2}$ \\
Observation and response time according to Article 7.4, local road, minimal & $1 \mathrm{~s}$ \\
\hline
\end{tabular}

Source: authors.

The calculation according to the current version of the ČSN 736380 standard is as follows:

$$
L_{p}=\frac{V_{z}}{V_{s n}} \times\left(D_{p}+D_{s}\right)=\frac{65}{5} \times(6.5+22)=370.5 \mathrm{~m}
$$

The overview distances are considered satisfactory because the standard minimum overview distance required of $370.5 \mathrm{~m}$ is less than the actual distance measured of $374 \mathrm{~m}$.

The calculation in the case of the stopping and starting of the slowest road vehicle, according to our proposed new calculation methodology, is as follows:

$$
\begin{gathered}
L_{p}=\frac{V_{z}}{3.6} \times\left(t_{1}+t_{a}+t_{k}\right) \\
t_{a}=\frac{V_{p} / 3.6}{V_{z}}=\frac{5 / 3.6}{1.2}=1.16 \mathrm{~s} \\
D_{0}=\frac{V_{z} \times t_{a}^{2}}{2}=\frac{1.2 \times 1.16^{2}}{2}=0.81 \mathrm{~m} \\
D_{x}=\left(D_{p}+D_{s}\right)-D_{0}=(6.5+22)-0.81=27.69 \mathrm{~m} \\
t_{k}=\frac{D_{x}}{V_{p} / 3.6}=\frac{27.69}{5 / 3.6}=19.34 \mathrm{~s} \\
L_{p}=\frac{V_{z}}{3.6} \times\left(t_{1}+t_{a}+t_{k}\right)=\frac{65}{3.6} \times(2+0.81+19.34)=406.25 \mathrm{~m}
\end{gathered}
$$

Even in this case, the overview distances are unsatisfactory because the minimum calculated length $L_{p}$ of $406.25 \mathrm{~m}$ (for a vehicle starting after stopping) is greater than the actual distance measured of $374 \mathrm{~m}$.

\section{Results and Discussion}

The first point of discussion is the willingness, or lack thereof, of the European Commission and the government to resolve the issues concerning the maintenance of level crossings. At present, in most cases, the only owner and manager is the state or the railway management authority. Everyone is aware of the disproportionately high number of level crossings, but no one wants to hear the administrator's call for the need to reduce these numbers. That said, reliable accident statistics and experience from abroad support such efforts. Within this context, it is clear that the safest level crossing is one that does not exist. The solution is a radical approach in the form of share-based financing of the maintenance of level crossings by the users from the regions and municipalities they are located in, or more appropriate and effective legal regulations. The European technical standards may specify the conditions for maintenance or removal of actual bypass routes with a maximum length.

According to the current inconsistent wording of national technical standards and the European standards and regulations, it can be stated that the existing standards and regulations are the source of the problem due to their possible misinterpretation. Therefore, it would be reasonable to discuss amendments to the European technical standards dealing with this subject. After updating the proposed 
calculation methodology, it would be possible to increase safety not only in the Czech Republic but also in EU countries.

Even though the SŽDC S 4/3 regulation is to be repealed, the current state of affairs, by virtue of all the related provisions, will continue to apply. The only solution is, therefore, to finalise the change within the ČSN 736380 standard. The revised Z2 amendment fully reflects the requirements of the current state of transport infrastructure and the technical characteristics of vehicles.

Overview distances are now satisfactory in many places. The result would be to limit cases by the application of measures leading to misinterpretations of the current wording of this document, especially the widely used combination of warming crosses and the mark No. P6 "Stop, give way" (see Table 7). The calculation above demonstrates that the standard does not consider this situation, and therefore, the calculation methodology is not applicable to this variant. On this basis, it can be concluded that it is necessary to apply a new calculation methodology, for example, the proposed methodology, to national standards and, in turn, to the technical specifications for the safe interoperability of level crossings.

Table 7. Comparison of standard values $\mathrm{L}_{\mathrm{p}}$ and calculated values if P6 warning sign "Stop, give way!" is installed.

\begin{tabular}{ccccccc}
\hline \multirow{2}{*}{ Length of the Crossing 6.5 $\mathbf{~ m}$} & \multicolumn{6}{c}{ Line Speed $\mathbf{V}_{\mathbf{z}}[\mathbf{k m} / \mathbf{h}]$} \\
\cline { 2 - 7 } & $\mathbf{1 0}$ & $\mathbf{2 0}$ & $\mathbf{3 0}$ & $\mathbf{4 0}$ & $\mathbf{5 0}$ & $\mathbf{6 0}$ \\
\hline ČSN 73 6380 Z1 & 57 & 114 & 171 & 228 & 285 & 342 \\
Recalculated for P6 & 60 & 119 & 179 & 239 & 299 & 358 \\
\hline \multicolumn{7}{c}{ Source: authors. }
\end{tabular}

For illustrative purposes, it is necessary to highlight the difference between the values given by the standard and the calculation with regard to the adjustment of the local road and line speeds. The differences do not seem so great, but it is important to realise that these are minimum values (see Figure 6).

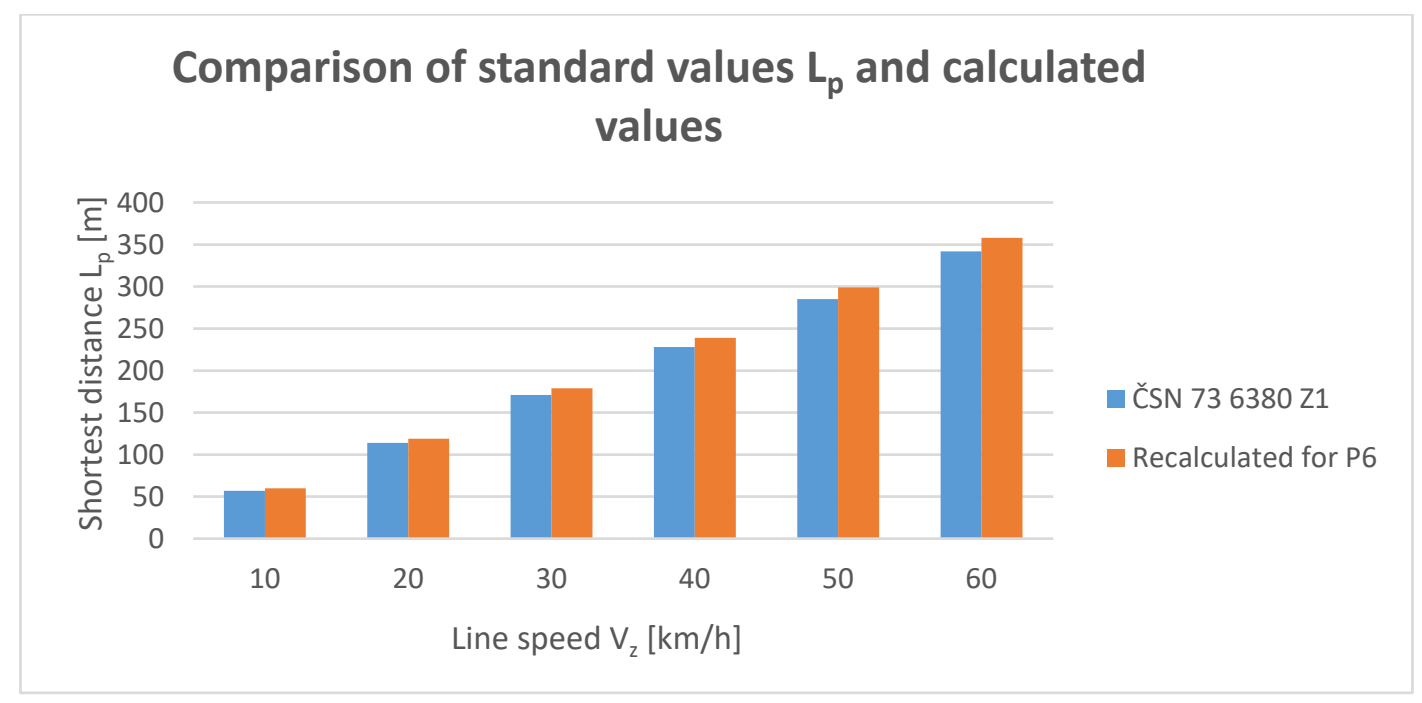

Figure 6. Comparison of standard values $\mathrm{L}_{\mathrm{p}}$ and calculated values if P6 warning sign "Stop, give way!" is installed.

With regards to the signalling device, the disproportionate prolongation of the pre-ringing times is associated with a poor assessment of the speed of the slowest vehicle. Here, however, the described change in the calculation would partially help. It is definitely necessary to support efforts to gradually deploy modern LED signal lighting and to modernise existing equipment because the visibility of current signal lighting at intersections is really poor. This situation is largely related to obsolete technology, but also to the cost of replacement, which is relatively high due to the complexity of 
and necessity for supervisory adjustments. Support for LED deployment is not even on the side of the standard.

\section{Conclusions}

The aim of this article is to draw attention to fundamental shortcomings in the area of level crossing safety. This issue is well-known among the general public. Despite the accident rate remaining stubbornly high, investment in this area is lacking. Unfortunately, few people realise that the responsibility for this situation not only lies with irresponsible road users but also with the current state of legislation and the unusually high number of level crossings. The consequence of the latter is that it has resulted in the unilateral financing of maintenance, which, in turn, has generated a reluctance to remove or reconstruct dangerous and unnecessary level crossings.

As was to be expected, tilting barriers proved to be the safest option. The recommendation should, therefore, be clear with regards to this. Unfortunately, there are many locations where they should be installed, but where it is often technically not possible to do so. The large percentage of accidents at level crossings with interlocking safety devices requires further assessment of the basic safety parameters in the calculation of visibility conditions. Due to the cancelled change to the ČSN 736380 Z2 standard, the correctness of the calculation was verified in its current form. This turned out to be wrong because it did not allow for the slowest vehicle to stop completely. This finding significantly changes the situation and creates a potential danger at all level crossings without barriers and with only the P6 warning sign "Stop, give way!". This is not helped by the lack of compliance with regulations, laws and standards, which leads to misinterpretations and the adaptation of provisions to current needs, which is not acceptable. Given the seriousness of the errors found, it is necessary to repeal the disputed regulations and to promptly update and amend the applicable standards, decrees and laws.

Urgent efforts are required to solve these elementary problems. It is paramount to start by significantly reducing the number of level crossings. This can only be achieved through close cooperation between the state, regions and municipalities. Of equal importance is the support of the general public. All proposals will only be effective if they strictly adhere to the rules, regulations and laws. This can be greatly helped through innovative education programmes aimed at increasing the understanding of the basic functions of CSE.

It is also necessary to evaluate the possible extension of the methodology, which will form the basis for future research, and which should be based on the new methodology presented. The case study has also raised further questions that need to be considered. One of the most important issues is the unification of individual national standards into one supranational standard that could be implemented by the European Union by decree.

Another solution is the adoption of technical standards that would prohibit the construction of level crossings in places where the safety and smoothness of road traffic flows are not maintained. Within this context, the adopted technical measures should include the simplification and clarity of the traffic situation near dangerous level crossings. Last but not least, when constructing new railway lines and upgrading existing lines, it is important to build level crossings which completely eliminate collisions between trains and road vehicles. All these issues will be the subject of further research.

Author Contributions: V.L'. and M.S. conceived and designed the manuscript; they elaborated its methodology, processed the literature review, verified the results and performed the experiments; J.M. performed individual calculations, realized the final manuscript corrections and supervised the formal revision of the manuscript. All authors have read and agreed to the published version of the manuscript.

Funding: This research received no external funding.

Conflicts of Interest: The authors declare no conflict of interest. 


\section{References}

1. DIČR; Railway Safety Inspection Office. Emergency Statistic. Praha, 2019. Available online: http://www.dicr.cz/statistiky-mimoradnych-udalosti (accessed on 27 February 2019).

2. Czech Republic, 1997. Act No. 13/1997 Coll., on Road Traffic, as Amended by Amended. (C) AION CS 2010-2019. Available online: https://www.zakonyprolidi.cz/cs/1997-13 (accessed on 15 February 2019).

3. Czech Republic, 1997. Act No 22/1997 Coll., on the Technical Requirements for Products, and on a Change and Addition to Certain Laws, as Amended by Amended. (C) AION CS 2010-2019. Available online: https://zakonyprolidi.cz/cs/1997-22 (accessed on 19 February 2019).

4. Czech Republic, 2000. Act no. 361/2000 Coll., On Road Traffic and on Changing Certain Acts, as Amended by Amended. (C) AION CS 2010-2019. Available online: https://www.zakonyprolidi.cz/cs/2000-361 (accessed on 19 February 2019).

5. Č́SN EN 12368 ED. 2, 2016. In Traffic Control Equipment-Signal Heads. [Ǩizení Dopravy na Pozemních Komunikacích-Návěstidla]; Český Normalizační Institut: Prague, Czech, 2016.

6. ČSN 34 2650, 2010. In Railway Signalling and Interlocking Equipment-Level Crossing Protection Equipment [Železniční Zabezpečovací Zařizení-Přejezdová Zabezpečovací Zařizení]; Český normalizační Institut: Prague, Czech, 2010.

7. ČSN 73 6101, 2018. In Design of Highways and Motorways. [Projektování Silnic a Dálnic]; Český normalizační Institut: Prague, Czech, 2018.

8. ČSN 73 6102, 2007. In Design of Intersection on Highways [Projektování Křžovatek na Silničních Komunikacích]; Český normalizační Institut: Prague, Czech, 2007.

9. Ambros, J.; Perůtka, J.; Skládaný, P.; Tučka, P. Enhancing the insight into Czech railway level crossings' safety performance. Int. J. Rail Transp. 2020, 8, 99-108. [CrossRef]

10. Cai, N.; Chen, H.; Li, Y.; Peng, Y. Intrusion Detection and Tracking at Railway Crossing. In Proceedings of the International Conference on Artificial Intelligence and Advanced Manufacturing, Dublin, Ireland, 17-19 October 2019.

11. Garmabaki, A.H.S.; Marklund, S.; Thaduri, A.; Hedström, A.; Kumar, U. Underground pipelines and railway infrastructure-failure consequences and restrictions. Struct. Infrastruct. Eng. 2020, 16, 412-430. [CrossRef]

12. Rukmana, A.; Ikhsan, A.F.; Etnisa, M.M.; Sulisawati, H.; Nurichsan, I. Railway level crossing warning design in rural area using ultrasonic sensor and wireless communication. J. Phys. Conf. Ser. 2019, 1402, 033084. [CrossRef]

13. Saunders, W.J.; Mousa, S.R.; Codjoe, J. Market basket analysis of safety at active highway-railroad grade crossings. J. Saf. Res. 2019, 71, 125-137. [CrossRef]

14. Wei, Z.; Núñez, A.; Liu, X.; Dollevoet, R.; Li, Z. Multi-criteria evaluation of wheel/rail degradation at railway crossings. Tribol. Int. 2020, 144. [CrossRef]

15. Widyastuti, H.; Utami, A.; Dzulfiqar, Z.M. Model of queuing in the railway level crossing (case study: Imam Bonjol railway level crossing in Blitar). IOP Conf. Ser. Mater. Sci. Eng. 2019, 650, 012053. [CrossRef]

16. Gašparík, J.; Abramović, B.; Halás, M. New graphical approach to railway infrastructure capacity analysis. Promet-Traffic-Traffico 2015, 27, 283-290. [CrossRef]

17. Gašparík, J.; Abramović, B.; Zitrický, V. Research on dependences of railway infrastructure capacity. Teh. Vjesn. 2018, 25, 1190-1195.

18. Meško, P.; Gašparík, J.; Lalinská, J. Railway capacity issues on slovak international corridors. In Proceedings of the International Conference, 21st International Scientific Conference Transport Means 2017, Vilnius, Lithuania, 20 September 2017; p. 436.

19. Badanjak, D.; Barić, D.; Novačko, L. Current safety situation at level crossings in Croatia and the future research. WIT Trans. Built Environ. 2009, 108, 595-604.

20. Addabbo, T.; Della Giovampaola, C.; Fort, A.; Mugnaini, M.; Pozzebon, A.; Toccafondi, A.; Vignoli, V. Target measurements influence on level crossing detection system safety determination. Measurement 2019, 135, 547-554. [CrossRef]

21. Cai, N.; Chen, H.; Li, Y.; Peng, Y. Intrusion Detection and Tracking at Railway Crossing. ACM International Conference Proceeding Series. Available online: https://www.scimagojr.com/journalsearch.php?q= 11600154611\&tip $=$ sid\&clean $=0$ (accessed on 19 February 2019). 
22. Mane, S.S.; Shah, S.A.K. Object Tracking and Analysis for Detecting Various Situations at Level Crossings of Railway-Road. In Proceedings of the 2017 International Conference on Computing, Communication, Control and Automation, ICCUBEA 2017, Pune, India, 17-18 August 2017.

23. Taillandier, V. Smart Level Crossing. In Proceedings of the 2018 16th International Conference on Intelligent Transport System Telecommunications, ITST 2018, Lisboa, Portugal, 15-17 October 2018.

24. Kampf, R.; Stopka, O.; Kubasakova, I.; Zitricky, V. Macroeconomic Evaluation of Projects Regarding the Traffic Constructions and Equipment. Procedia Eng. 2016, 1538. [CrossRef]

25. Zitrický, V.; Černá, L.; Abramovič, B. The Proposal for the Allocation of Capacity for International Railway Transport. Procedia Eng. 2017, 994. [CrossRef]

26. Koper, E.; Kochan, A.; Gruba, Å. Simulation of the Effect of Selected National Values on the Braking Curves of an ETCS Vehicle. In Development of Transport by Telematics; Springer: New York, NY, USA, 2019.

27. Lee, M.K.; Bhandari, B. The application of aerodynamic brake for high-speed trains. J. Mech. Sci. Technol. 2018, 32, 5749-5754. [CrossRef]

28. Lubenets, N.A.; Lubenets, T.N. Train braking mode. In Naukovyi Visnyk Natsionalnoho Hirnychoho Universytetu; National Mining University of Ukraine: Dnipro, Ukraine, 2012; Volume 6, pp. 41-46.

29. Peng, X.; Zhou, Y.Y.; Li, Q.Y.; He, X.Q. Brake distance calculation of CRH. In Proceedings of the 2012 4th Electronic System-Integration Technology Conference (ESTC), Amsterdam, The Netherlands, 17-20 September 2012.

30. Thurston, D.F. Deceleration rates for safe braking distance calculations. In 2017 Joint Rail Conference; JRC: Philadelphia, PA, USA, 2017.

31. Thurston, D.F. Adhesion considerations in Safe Braking distance calculations. In 2015 Joint Rail Conference; JRC: Philadelphia, PA, USA, 2015.

32. Powrie, W.; Le Pen, L.; Milne, D.; Watson, G.; Harkness, J. Behaviour of under-track crossings on ballasted railways. Transp. Geotech. 2019, 21. [CrossRef]

33. Kobaszyńska-Twardowska, A.; Galant, M.; Gill, A.; Smoczyński, P.; Kadziński, A. Methodology of research on drivers perception at level crossings. In Proceedings of the MATEC Web of Conferences, 12th International Road Safety Conference GAMBIT 2018, Gdaňsk, Poland, 12 April 2018.

34. Larue, G.S.; Watling, C.N.; Black, A.A.; Wood, J.M. Getting the Attention of Drivers Back on Passive Railway Level Crossings: Evaluation of Advanced Flashing Lights. Transp. Res. Rec. J. Transp. Res. Board 2019, 2673, 789-798. [CrossRef]

35. Read, G.J.M.; Beanland, V.; Stanton, N.A.; Grant, E.; Stevens, N.; Lenné, M.G.; Thomas, M.; Mulvihill, C.M.; Walker, G.H.; Salmon, P.M. From interfaces to infrastructure: Extending ecological interface design to re-design rail level crossings. In Cognition, Technology and Work; Springer: New York, NY, USA, 2019.

36. Smoczyński, P.; Gill, A.; Kadziński, A. Modelling of railway accidents with accimap-Case study. In Proceedings of the Transport Means, International Conference, Palanga , Lithuania, 2-4 October 2019; p. 113.

37. Zaman, S.U.; Hossairr, S.; Shahnaz, C. Automatic Rail Crossing Alarming System. In Proceedings of the 2018 IEEE International WIE Conference on Electrical and Computer Engineering, WIECON-ECE 2018, Chonburi, Thailand, 14-16 December 2018; p. 129.

38. Stopka, O.; Šimková, I.; Konečný, V. The quality of service in the public transport and shipping industry. Nase More 2015, 62, 126-130. [CrossRef]

39. Černá, L.; Zitrický, V.; Abramović, B. Methodical Manual for a Set of Transport Regulations in Railway Passenger Transport. LOGI-Sci. J. Transp. Logist. 2020, 11, 13-24. [CrossRef]

40. Skrúcaný, T.; Kendra, M.; Stopka, O.; Milojević, S.T.; Figlus, T.; Csiszár, C. Impact of the Electric Mobility Implementation on the Greenhouse Gases Production in Central European Countries. Sustainability 2019, 11, 4948. [CrossRef]

41. Akaateba, M.A.; Amoh-Gyimah, R.; Amponsah, O. Traffic safety violations in relation to drivers' educational attainment, training and experience in Kumasi, Ghana. Saf. Sci. 2015, 75, 156-162. [CrossRef]

42. Salmon, P.M.; Read, G.J.M.; Stanton, N.A.; Lenné, M.G. The crash at Kerang: Investigating systemic and psychological factors leading to unintentional non-compliance at rail level crossings. Accid. Anal. Prev. 2013, 50, 1278-1288. [CrossRef]

43. ČSN 73 6380, 2004. Railway Level Crossings and Pedestrian Crossings. [Železniční Přejezdy a Přechody]; Český normalizační Institut: Prague, Czechia, 2004. 
44. ČSD S 4/3, 1985. Regulation for the Management and Maintenance of Level Crossings. [Předpis pro Správu a Udržování Železničních Přejezdů a Přechodi̊]; Nakladatelství Dopravy a Spojů: Prague, Czechia, 1985.

45. KUBO, Jaroslav. Rationalization of Railroad Crossings in the South Bohemian Region [Racionalizace Železničních Přejezdů na Území Jihočeského Kraje]. Bachelor Thesis, Institute of Technology and Business in České Budějovice. 2019. Available online: https://is.vstecb.cz/th/vfulx/ (accessed on 5 February 2020).

46. Šimková, I.; Konečný, V.; Liščák, S.; Stopka, O. Measuring the Quality Impacts on the Performance in Transport Company. Transp. Probl. 2015, 10, 113-124. [CrossRef]

47. Cempírek, V.; Rybicka, I.; Ljubaj, I. Development of Electromobility in Terms of Freight Transport. LOGI-Sci. J. Transp. Logist. 2019, 10, 23-32. [CrossRef]

(C) 2020 by the authors. Licensee MDPI, Basel, Switzerland. This article is an open access article distributed under the terms and conditions of the Creative Commons Attribution (CC BY) license (http://creativecommons.org/licenses/by/4.0/). 